\title{
LIGHT MICROSCOPIC AND FLOW CYTOMETRIC DETECTION OF APOPTOSIS AND NECROSIS OF NEUTROPHILS IN THE MAMMARY GLAND OF THE VIRGIN HEIFER
}

\author{
Z. SLÁDEK ${ }^{1}$, D. RYŠÁNEK ${ }^{2}$, M. FALDYNA ${ }^{2}$ \\ ${ }^{1}$ Department of Morphology, Physiology and Veterinary Sciences, Mendel University of Agriculture and \\ Forestry, Brno, Czech Republic \\ ${ }^{2}$ Veterinary Research Institute, Brno, Czech Republic \\ Received February 2, 2001 \\ Accepted May 28, 2001 \\ Abstract \\ Sládek Z., D. Ryšánek, M. Faldyna: Light Microscopic and Flow Cytometric Detection \\ of Apoptosis and Necrosis of Neutrophils in the Mammary Gland of the Virgin Heifer. Acta Vet. \\ Brno 2001, 70: 149-155. \\ Flow cytometry analysis of discrimination of apoptotic and necrotic neutrophils and their \\ distribution on dot plots using cells influx induced by intramammary administration of buffered \\ saline was verified by light microscopy. Twenty mammary glands of five nonpregnant heifers were \\ used and samples of mammary gland lavages were collected before (control) and 24, 48, 72, and \\ $96 \mathrm{~h}$ after treatment and examined by light microscopy and flow cytometry with Annexin $\mathrm{V}$ and \\ propidium iodide staining. Verification of flow cytometry method was provided by morphological \\ features of leukocytes in light microscopy and by changes in differential cell counts during induced \\ influx. Detection of apoptotic and necrotic neutrophils was made using backgating technique. \\ There were no significant differences between flow cytometry and light microscopy methods in \\ the percentages of apoptotic neutrophils. By contrary, differences of high significance between \\ methods in the percentages of necrotic neutrophils was determined. It can be concluded that the \\ identification of apoptotic and necrotic neutrophils by flow cytometry is a suitable method for the \\ detection of apoptotic neutrophils of the bovine mammary gland. However, a single trait cannot be \\ regarded as an unambiguous proof of cell necrosis. Gating of a major population of neutrophils \\ seems unsuitable, contrary to backgating, because the majority of apoptotic and necrotic \\ neutrophils was localised out of a major population of neutrophils. \\ Apoptosis, necrosis, neutrophil, mammary gland, bovine
}

Neutrophils constitute the cellular component of the defence system of the bovine mammary gland (Paape and Wergin 1977). Since their life span is very short (1 to 2 days) and their return into the blood circulation is impossible (Hughes et al. 1997), they die in the mammary gland by either necrosis followed by lysis (Nickerson et al. 1986; Paape et al. 1990), or apoptosis (Sládek and Ryšánek 2000a, 2001) to which they are predisposed after leaving the blood circulation (Raff 1992).

So far, both types of in vivo or in vitro death of bovine mammary gland neutrophils were detected largely by specific morphologic characteristics of apoptotic and necrotic cells using light and electron microscopic methods (Nickers on et al. 1985, 1986; Pa ape et al. 1990; Lintner and Eberhart 1990; Sládek and Ryšánek 1999ab, 2000ab, 2001). However, such procedures are considered less effective and unsuitable for the examination of larger sets of samples owing to high labour and material costs.

Apparently a more suitable is the method of identification of apoptotic or necrotic cells which detects biochemical alterations occurring on the surface of the cytoplasmatic membrane (Vermes et al. 1995). Apoptosis is recognisable already at an early stage by translocation of phosphatidyl serine (PS) from the cytosolic side of the cytoplasmatic membrane to its outer surface (Fadok et al. 1992). This translocation can be visualised by

Address for correspondence:

MVDr. Z. Sládek, PhD

MVDr. Z. Sládek, PhD.
Dept. of Morphology, Physiology and Veterinary Sciences

Mendel University of Agriculture and Feterin

Zemědělská 1,61300 Brno, Czech Republic
Phone: +420545133151

Fax: +420545211128

http://www.vfu.cz/acta-vet/actavet.htm 
staining with fluorescein-labelled Annexin V (Koopman et al. 1994; Zhang et al. 1997; van England et al. 1998), which shows a high natural affinity to PS (Martin et al. 1995; Zhang et al 1997). Since this method detects both apoptotic and necrotic cells, it must be completed by additional staining. Suitable for this purpose is propidium iodide which penetrates into necrotic cells and stains their nuclei, but for which the cell membrane of apoptotic cells is impermeable (Vermes et al. 1995).

This biochemical method was originally developed for the identification of isolated necrotic and apoptotic human lymphocytes. Data obtained by this technology indicate that the staining of PS with labelled Annexin V is a universal tool for the detection of apoptosis that can be used in most, if not all, cell types irrespective of the initiating trigger (Vermes et al. 2000). Van Oostveldt et al. (1999) modified this method for the detection of induced apoptosis and necrosis of isolated bovine blood neutrophils in vitro. No data on its use for the detection of apoptosis and necrosis of bovine mammary gland neutrophils were found in available literature.

The objectives of this work were to verify the flow cytometric method for the identification of apoptotic and necrotic bovine mammary gland neutrophils, to compare its results with those of light microscopy, and to use the method for the analysis of distribution and discrimination of apoptotic and necrotic neutrophils and their dynamics under in vivo conditions of induced influx.

\section{Materials and Methods}

Animals

The experiments were carried out in five clinically normal Holstein $\times$ Bohemian Red Pied heifers aged 15 to 18 months.

\section{Influx induction}

All four glands of each heifer were washed with $20 \mathrm{ml}$ of sterile buffered $0.01 \mathrm{M}$ physiological saline (PBS), $\mathrm{pH}$ 7.4 , to obtain control samples of cell populations. Cell influx was then induced by intramammary administration of PBS (10 ml). Samples of mammary lavages (ML) were obtained. The first sample was collected from the left forequarter at 24 hours after the administration of PBS. Subsequent samples were collected at 24-h intervals from the remaining quarters in the following order: left hindquarter $\rightarrow$ right forequarter $\rightarrow$ right hindquarter. No bacterial growth was detectable in any of ML samples by culture on blood agar plates (5\% washed sheep erythrocytes) and aerobic incubation at $37^{\circ} \mathrm{C}$ for $24 \mathrm{~h}$.

\section{Cell processing}

Total cell counts were determined by the haemocytometer. The trypan blue dye exclusion test demonstrated viability in at least $97.3 \%$ of cells in each ML. The cell suspensions were centrifuged at $4{ }^{\circ} \mathrm{C}$ and $200 \times g$ for $10 \mathrm{~min}$. One $\mathrm{ml}$ of the supernatant was removed and retained to be used for resuspension of the pellet and the remaining supernatant was decanted.

Light microscopic (LM) assessment of apoptosis and necrosis of neutrophils

One smear of each processed cell suspension was prepared and stained panoptically by the Papanicolau method (Bessis 1973). Differential cell counts were determined in ML by enumeration of at least 200 cells. Apoptosis and necrosis of neutrophils were assessed by identifying specific morphologic features using oil-immersion microscopy (magnification factor of objective $100 \times$ ) (Sládek and Ryšánek 2000a).

Flow cytometric (FCM) assessment of apoptosis and necrosis of neutrophils

Apoptotic and necrotic neutrophils were enumerated by FCM after simultaneous staining with Annexin V labelled with fluorescein isothiocyanate (FITC) and propidium iodide (PI) as described by Vermes et al. (1995). The commercial Annexin-V-FLUOS Staining Kit (Boehringer Mannheim, GmbH, Mannheim, Germany) was used according to the manufacturer's instructions.

Briefly: $500 \mu \mathrm{l}$ of the incubation buffer $\left(10 \mathrm{mM}\right.$ Hepes/ $\mathrm{NaOH}, \mathrm{pH} 7.4 ; 140 \mathrm{mM} \mathrm{NaCl} ; 2.5 \mathrm{mM} \mathrm{CaCl}_{2}$ ) was mixed with $10 \mu \mathrm{l}$ of PI and $10 \mu \mathrm{l}$ of FITC-Annexin-V solutions. Cell suspension was adjusted to $1 \times 10^{6}$ per $1 \mathrm{ml}$ in $100 \mu \mathrm{l}$ of fresh incubation buffer containing PI and FITC-Annexin-V and the suspension was analysed after $15 \mathrm{~min}$ of incubation at room temperature by FCM (FACS Calibur apparatus, Beckton Dickinson, Mountain View, California, USA) by differentiation of at least 10.000 cells. Dot plots were evaluated qualitatively and quantitatively using the WinMDI 2.8 software (Trotter 2000). 
The data obtained at each point of time were displayed on two dot plots. The first dot plot (FDP) was designated to provide two-parameter leukocyte differential counts by discriminating leukocytes in terms of size (determined by forward light scatter - FSC), nucleus morphology, and cytoplasm granularity (determined by side light scatter SSC). The second dot plot (SDP) was designated to provide two-parameter analysis of apoptotic and necrotic neutrophils by discriminating the population of neutrophils in terms of Annexin V positivity (FITC+ determined by green fluorescence on FL1) and PI positivity (PI+ determined by red fluorescence on FL3).

The technique of backgating was applied to identify apoptotic and necrotic neutrophils (detected on SDP) on FDP. Briefly, neutrophils were first identified on a plot (FDP) of forward-scatter versus side-scatter by their scatter parameters. This population of purified neutrophils was than followed on a plot (SDP) with green fluorescence (FITC+) on the $X$-axis (FL1) versus red fluorescence (PI+) on the $Y$-axis (FL3). Thereafter, apoptotic and necrotic neutrophils from SDP were backgated on FDP where they generate distinct coloured clusters.

Statistics

The results underwent multifactorial analysis of variance for the determination of significance of variation sources (time points, methods and udder quarters). The significance of differences between mean percentages of apoptotic neutrophils and necrotic neutrophils determined by LM or FCM was tested by Scheffe's method (STAT PLUS ver. 1.1 1993). The correlation between the percentages of apoptotic and necrotic neutrophils determined under both methods was tested by calculation of correlation coefficients. The STAT PLUS software (version 1.1 1993) was used.

\section{Results}

Analysis of variability sources

Time points and methods were found to be significant variability sources $(P<0.01)$, whereas udder quarters were not. The significance of between-method and among-time point differences could be tested (see below).

Total and differential cell counts during induced influx

The induced influx was characterised as a prompt, reversible, and time-dependent accumulation of cells in the mammary gland, as shown in Fig. 1. The dominant type in the cell population of control samples were macrophages, followed by lymphocytes and neutrophils. On the other hand, neutrophils prevailed over other cell types at $24 \mathrm{~h}$ after induced influx. Fig. 2 shows a gradual decrease in the proportion of neutrophils at 48 and 96 $\mathrm{h}$ after induced influx, and comparison of the proportions of neutrophils during induced influx as represented by LM and FCM.

Flow cytometric distribution of neutrophils gated for scatter parameters

The FCM distribution of cell populations as represented on FDP corresponded to their morphological characteristics. The cluster of neutrophils on FDP was situated to the left (FCS) and above (SSC) the cluster of lymphocytes and macrophages (Plate II, Fig. 3).

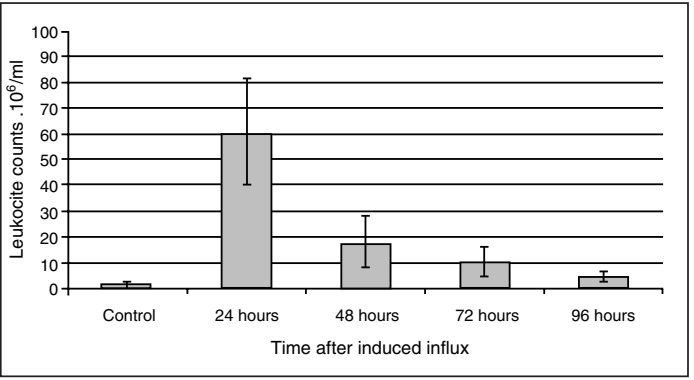

Fig. 1. Total leukocyte counts in ML after influx induction with PBS. Means \pm SD for five heifers/time point are given.

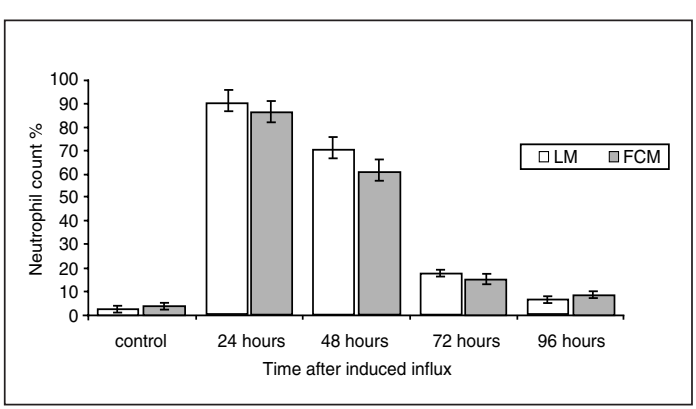

Fig. 2. Comparison of percentages of neutrophils in ML after influx induction with PBS detected in light microscopy (open columns) and flow cytometry (hatched columns). There were no significant differences between the values for methods. Means \pm SD for five heifers/time point are given. 
Light microscopy of apoptotic and necrotic neutrophils

Beside morphologically normal cells, neutrophils with aberrant structures typical of apoptosis or necrosis were seen. Apoptotic neutrophils showed condensation of chromatin (karyopyknosis), merging and shrinking of nuclear segments, cell shrinking, and fragmentation into apoptotic bodies. Typical signs of necrosis included whole-cell and nuclear segment swelling, spherical shape, loss of pseudopodia, and finally karyolysis and cell lysis (data not shown, for details see Sládek and Ryšánek 1999a, 2000a).

Flow cytometric distribution of neutrophils gated for Annexin V and propidium iodide

Neutrophils stained with FITC-Annexin V and PI could be distinguished in SDP in three quadrants. The lower left quadrant represents intact-viable neutrophils which exclude PI and do not bind Annexin V (FITC-/PI-), the lower right quadrant represents apoptotic neutrophils binding Annexin V, but with preserved cell membrane integrity (FITC+/PI-), and the upper right quadrant represents necrotic neutrophils binding Annexin $\mathrm{V}$ and showing PI uptake (FITC+/PI+) (Plate II, Fig. 3, Plate III, Fig. 4).

The three distinct neutrophil populations [viable (FITC-/PI-), apoptotic (FITC+/PI-) and necrotic (FITC+/PI+)] represented on SDP were also identified on FDP by technique of backgating. Neutrophils formed three distinct clusters on FDP (Fig. 3-4). Viable neutrophils (FITC-/PI-) formed a cluster situated to the left of (FSC) and above (SSC) the cluster of lymphocytes and macrophages. The smaller apoptotic neutrophils (FITC+/PI-) with condensed nuclei were situated to the left of and below viable neutrophils (FITC-/PI-). Apoptotic bodies (FITC+/PI-) formed a cluster at the left bottom corner of the dot plot above debris. The swollen necrotic neutrophils with desegmented compact nuclei (FITC+/PI+) were situated below the region of viable neutrophils towards lymphocytes.

Kinetics of neutrophil apoptosis and necrosis during induced influx

The proportions of viable (negative by trypan blue dye exclusion test), apoptotic, and necrotic neutrophils as determined by LM and FCM during induced influx are shown in Table 1. No apoptotic and almost no necrotic $(\leq 0.1 \%)$ cells were detected by any of the methods in the population of neutrophils in control samples. The percentages of apoptotic and necrotic neutrophils reached peak values at $48 \mathrm{~h}$ after induction and decreased subsequently at $72 \mathrm{~h}$ and $96 \mathrm{~h}$. Data in Table 1 show proportion of apoptotic neutrophils detected in LM and FCM. Morever, there are shown neutrophils with damaged cytoplasmatic membranes detected by the trypan blue exclusion test, necrotic neutrophils detected by morphological features in LM, and necrotic neutrophils (FITC+/PI+) after staining with FITC Annexin-V and PI in FCM.

Table 1.

The proportions of viable, apoptotic, and necrotic neutrophils determined by LM and FCM during induced influx

\begin{tabular}{|c|c|c|c|c|c|}
\hline \multirow{2}{*}{$\begin{array}{c}\text { Time } \\
\text { points }\end{array}$} & \multicolumn{2}{|c|}{ Apoptotic neutrophils } & \multicolumn{2}{c|}{ Necrotic neutrophils } & Trypan blue \\
\cline { 2 - 6 } & $\mathrm{LM}^{\mathrm{a}}$ & $\mathrm{FCM}^{\mathrm{a}}$ & LM $^{\mathrm{a}}$ & $\mathrm{FCM}^{\mathrm{a}}$ & positive neutrophis $^{\mathrm{a}}$ \\
\hline control & $0 \pm 0$ & $0.1 \pm 0.1$ & $0.3 \pm 0.2$ & $0.1 \pm 0.1$ & $0.03 \pm 0.03$ \\
\hline $24 \mathrm{~h}$ & $8.3 \pm 2.9$ & $9.7 \pm 3.9$ & $2.4 \pm 1.4$ & $6.8 \pm 2.5^{* *}$ & $1.1 \pm 0.8$ \\
\hline $48 \mathrm{~h}$ & $20.8 \pm 3.6$ & $22.2 \pm 10.1$ & $2.3 \pm 1.4^{* *}$ & $9.4 \pm 3.2^{* *}$ & $1.1 \pm 0.5$ \\
\hline $72 \mathrm{~h}$ & $16.1 \pm 1.8$ & $14.3 \pm 1.9$ & $1.8 \pm 0.7$ & $6.1 \pm 3.3^{* *}$ & $0.16 \pm 0.1$ \\
\hline $96 \mathrm{~h}$ & $5.1 \pm 4.1$ & $2.4 \pm 1.6$ & $0.5 \pm 0.4$ & $0.2 \pm 0.1$ & $0.06 \pm 0.07$ \\
\hline
\end{tabular}

a aritmetic mean and \pm S.D.

** significant differences $P<0.01$ (light microscopy and flow cytometry detected necrotic neutrophils versus trypan blue positive neutrophils) 
Statistical difference was observed between proportion of necrotic neutrophils detected by trypan blue dye exclusion test and LM detection $(P<0.01)$ and between proportion of necrotic neutrophils detected by trypan blue dye exclusion test and FCM detection $(P<0.01)$.

Highly significant correlations were found for data on apoptotic and necrotic neutrophil percentages determined by LM and FCM during induced influx $\left[\mathrm{r}_{\text {(apoptosis) }}=0.97, P<0.01\right.$, $\left.\mathrm{n}=20 ; \mathrm{r}_{\text {(necrosis) }}=0.96, P<0.05, \mathrm{n}=20\right]$.

\section{Discussion}

Flow cytometric method for the detection of apoptosis and necrosis of neutrophils of the bovine mammary gland was tested and verified by comparison with results of light microscopy. The study is a continuation of our earlier experiments in which the detection of apoptotic and necrotic neutrophils isolated from the bovine mammary gland by light, electron, and fluorescence microscopic techniques (Sládek and Ryšánek 1999ab, 2000ab, 2001) was investigated.

Unlike our previous investigations, we used the flow cytometric method described by Vermes et al. (1995) in this study. The method is based on the binding of FITC-conjugated Annexin $\mathrm{V}$ on the surface of the cytoplasmatic membrane of apoptotic cells and intercalation of PI in nuclei of necrotic cells.

Our study of the interaction of Annexin V with apoptotic cells were encouraged by the observations of Fadok et al. (1992). It was inspired from the knowledge that Annexin $\mathrm{V}$ binds, in the presence of calcium ions, with the phospholipid membrane when PS is present. Annexin V is a potent discriminator between viable and apoptotic cells (Vermes et al. 1995). Simultaneous staining with FITC-conjugated Annexin V and PI allowed us to distinguish between viable, apoptotic, and necrotic neutrophils. While viable neutrophils were negative for both the stains, apoptotic neutrophils with intact cytoplasmatic membrane stained with FITC-Annexin V and necrotic neutrophils with both FITC-Annexin V and PI.

By backgating technique, the side-by-side representation of viable, apoptotic, and necrotic neutrophils stained with Annexin V and PI on SDP corresponds to their characteristic distribution in terms of size on FDP. The reasons are apparent. Initiating apoptosis is characterised by cell shrinking without damage to cell membrane integrity. As a consequence of this event, FSC decreases and SSC decreases or remains unchanged at this phase. Apoptotic bodies, as the final stage of this cell death type, can be identified as separate particles with low light scatter properties (S w at et al. 1991; Darzynkiewicz et al. 1992). On the other hand, necrotic cells swell in consequence of loss of cell membrane integrity and this cell damage results in an immediate increase in FSC and decrease in SSC (Dive et al. 1992). The major benefit of this method is that the combination of light scatter signals and analysis for specific fluorescein-labelled antibodies allows the identification of neutrophil subpopulations undergoing apoptosis or necrosis.

Our experiments were done using cell populations showing variable neutrophil purity which was highest at $24 \mathrm{~h}$ after influx induction. The period of neutrophil cumulation in the bovine mammary gland is limited, because these cells with a short life span die within 1 or 2 days (Paape et al. 1977). Therefore, the absolute and relative counts of neutrophils decreased markedly at 48 and $72 \mathrm{~h}$ after influx induction, respectively.

Our previous studies indicated that apoptosis predominated over necrosis in the elimination of bovine mammary gland neutrophils (Sládek and Ryšánek 2000b, 2001). This finding is consistent with the results of the present experiments, although the percentage of necrotic neutrophils was higher, than in cited papers mentioned (Sládek and Ryšánek 2000b, 2001). The significantly higher percentage of necrotic neutrophils (FITC+/PI+) in FCM as compared with the results of LM and the trypan blue dye exclusion test probably does not reflect the real in situ proportions, because the viability of the initial 
neutrophil population prior to processing was invariably $\geq 97.3 \pm 0.8 \%$. This discrepancy may have been caused by an artificial damage of the cell membrane integrity in some neutrophils during cell separation and processing resulting in the FITC+/PI+ pattern. A similar explanation was suggested by Van Oostveldt et al. (1999). It is therefore recommended to complete the FCM method of Vermes et al. (1995) with a cell viability test when the actual percentage of necrotic neutrophils is to be determined.

It can be concluded that the identification of apoptotic and necrotic cells as described by Vermes et al. (1995) is a suitable method for the detection of apoptotic neutrophils of the bovine mammary gland. However, firstly, a single trait (FITC+/PI+) cannot be regarded as an unambiguous proof of cell necrosis. Therefore, we recommend according to $\mathrm{Van}$ Oostveldt et al. (1999) to complete FCM always with a method which detects necrotic neutrophils, such as a cell viability test. Secondly, this desinterpretation of results may occur when only major a population of neutrophils is gated, because clusters of apoptotic and necrotic neutrophils are located out of this major population of neutrophils.

\section{Detekce apoptózy a nekrózy neutrofilních granulocytů virginní bovinní mléčné žlázy světelnou mikroskopií a průtokovou cytometrií}

Metodou světelné mikroskopie byla verifikována analýza diskriminace apoptotických a nekrotických neutrofilních granulocytů pomocí průtokové cytometrie a jejich distribuce na dot plotech a to s využitím influxu těchto buněk indukovaného intramammární aplikací pufrovaného fyziologického roztoku. Bylo vyšetřeno dvacet mléčných žláz pěti nepřipuštěných jalovic. Vzorky laváží mléčných žláz byly odebrány před (kontrola) a 24, 48, 72, a 96 hodin po indukci influxu a následně byly podrobeny analýze ve světelném mikroskopu a v průtokové cytometrii po obarvení Annexinem $\mathrm{V}$ a propidium jodidem. Verifikace výsledků průtokové cytometrie byla provedena světelnou mikroskopií podle morfologických vlastností leukocytů a změn v diferenciálních počtech buněk během indukovaného influxu. Detekce apoptotických a nekrotických neutrofilních granulocytů byla provedena technikou zpětného gatingu. Nebyly zjištěny žádné významné rozdíly mezi metodami světelné mikroskopie a průtokové cytometrie při detekci apoptotických neutrofilních granulocytů. Oproti tomu byl zjištěn statisticky vysoce významný rozdíl mezi metodami při detekci nekrotických neutrofilních granulocytů. Lze konstatovat, že průtoková cytometrie je vhodná pouze pro detekci apoptotických, nikoliv však nekrotických neutrofilních granulocytů bovinní mléčné žlázy. Použití pouze jednoho znaku k průkazu nekrózy není dostatečným prostředkem. Oproti technice zpětného gatingu se jeví ohraničení hlavního regionu granulocytů jako nevhodné, nebot většina apoptotických a nekrotických neutrofilních granulocytů je lokalizována mimo tento region.

\section{Acknowledgements}

Supported by Ministry of Agriculture of Czech Republic (MZE-MO3-99-01) and GA ČR (524/01/1290).

\section{References}

BESSIS, M. 1973: Living blood cells and their ultrastructure. Second edition, Springer-Verlag, New York, 1-754 DARZYNKIEWICZ, Z., BRUNO, S., DEL BINO, G., GORCZYCA, W., HOTZ, M.A., LASSOTA, P., TRAGANOS, F. 1992: Features of apoptotic cells measured by flow cytometry. Cytometry 13: 795-808

DIVE, C., GREGORY, C.D., PHIPPS, D. J., EVANS, D.L., MILNER, A.E., WYLLIE, A. H. 1992: Analysis and discrimination of necrosis and apoptosis (programmed cell death) by multiparameter flow cytometry. Biochim. Biophys. Acta 1133: 275

FADOK, V. A., VOELKER, D. R., CAMPBELL, P. A., COHEN, J. J., BRATTON, D. L., HENSON, P. M. 1992 :

Exposure of phosphatidylserine on the surface of apoptotic lymphocytes triggers specific recognition and removal by macrophages. J. Immunol. 148: 2207-2216

HUGHES, J., JOHNSON, R. J., MOONEY, A., HUGO, C., GORDON, K., SAVILL, J. 1997: Neutrophil fate in 
experimental glomerular capilary injury in the rat. Emigration exceeds in situ clearance by apoptosis. Am. J. Pathol. 150: 223-234

KOOPMAN, G., REUTELINGSPERGER, C. P., KUIJTEN, G. A., KEEHNEN, R. M., PALS, S. T., VAN OERS,

M. H. 1994: Annexin V for flow cytometric detection of phosphatidylserine expression on B cells undergoing apoptosis. Blood 84: 532-540

LINTNER, S., EBERHART, R. J. 1990: Effect of antibiotics on phagocyte reicruitment, function, and morphology in the bovine mammary gland during the early nonlacting period. Am. J. Vet. Res. 51: 533-542

MARTIN, S. J., REUTELINGSPERGER, C. P., McGAHON, A.J., RADAR, A., VAN-SCHIE, R. C., LAFACE, D. M., GREEN, D. R. 1995: Early distribution of plasma membrane phosphatidylserine is a general feature of apoptosis regardless of the initiating stimulus: inhibition by overexpression of Bcl-2 and Abl. J. Exp. Med. 182: $1545-1556$

NICKERSON, S. C., PAAPE, M. J., DULIN, A. M. 1985: Effect of antibiotics and vehicles on bovine mammary polymorphonuclear leukocyte morphologic features, viability, and phagocytic activity in vitro. Am. J. Vet. Res. 46, 2259-2265

NICKERSON, S. C., PAAPE, M. J., HARMON, R. J., ZIV, G. 1986: Mammary leukocyte response to drug therapy. J. Dairy Sci. 69: 1733-1742

PAAPE, M. J., PEARSON, R. E., WERGIN, W. P., GUIDRY, A. J. 1977: Enhancement of chemotactic response of polymorphonuclear leukocytes into the mammary gland and isolation from milk. J. Dairy Sci. 60: 53-62

PAAPE, M. J., WERGIN, W. P. 1977: The leukocyte as a defense mechanism. J. Am. Vet. Med. Assoc. 170: 12141223

PAAPE, M. J., NICKERSON, S. C., ZIV, G. 1990: In vivo effect of chloramphenicol, tetracycline, and gentamicin on bovine neutrophil function and morphologic features. Am. J. Vet. Res. 51: 1055-1061

RAFF, M. C. 1992: Social controls on cell survival and cell death. Nature 356: 397- 400

SLÁDEK, Z., RYŠÁNEK, D. 1999a: Morphological characteristic of somatic cells from mammary glands of unbred heifers. Vet. Med Czech 44: 205-214

SLÁDEK, Z., RYŠÁNEK, D. 1999b: Ultrastructure of phagocytes from mammary glands of non-pregnant heifers. Anat. Histol. Embryol. 28: 291-298

SLÁDEK, Z., RYŠÁNEK, D. 2000a: Morphology of apoptosis of polymorphonuclear leukocytes isolated from mammary glands of unbred heifers. Vet. Med. Czech 45: 71-81

SLÁDEK, Z., RYŠÁNEK, D. 2000b Apoptosis of polymorphonuclear leukocytes of the juvenile bovine mammary gland during induced influx. Vet. Res. 31: 553-563

SLÁDEK, Z., RYŠÁNEK, D. 2001 Neutrophil apoptosis during resolution of acute bovine mammary gland injury. Res. Vet. Sci. 70: 41-46

STAT-PLUS ver. 1.1. Brno, Veterinary Research Institute, 1993.

SWAT, W., IGNATOWICZ, L., KISIELOW, P. 1991: Detection of apoptosis of immature CD4+8+ thymocytes by flow cytometry. J. Immunol. Methods 137: 79

TROTTER, J. 2000: Windows multiple document interface flow cytometry application 2.8.

VAN ENGLAND, M., NIELAND, L. J., RAMAEKERS, F. C., SCHUTTE, B., REUTELINGSPERGER, C. P. 1998: Annexin V-affinity assay: a review on an apoptosis detection system based on phosphatidylserine exposure. Cytometry 31: 1-9

VAN OOSTVELDT, K., DOSOGNE, H., BURVENICH, C., PAAPE, M. J., BROCHEZ, V., VAN DEN EECKHOUT, E. 1999: Flow cytometric procedure to detect apoptosis of bovine polymorphonuclear leukocytes in blood. Vet. Immunol. Immunopathol. 70: 125-133

VERMES, I., HAANEN, C., STEFFERNS-NAAKEN, H., REUTELINGSPERGER, C. P. 1995: A novel assay for apoptosis: flow cytometry detection of phosphatidylserine expression on early apoptotic cells using fluorescein labelled Annexin V. J. Immunol. 184: 39-51

VERMES, I., HAANEN, C., REUTELINGSPERGER, C. 2000: Flow cytometry of apoptotic cell death. J. Immunol. Methods 243: 167-190

ZHANG, G., GURTU, V., KAIN, S. R., YAN, G. 1997: Early detection of apoptosis using a fluorescent conjugate of annexin V. Biotechnique 23: 525-531 
Plate II

Sládek Z. et al.: Light...pp. 147-155
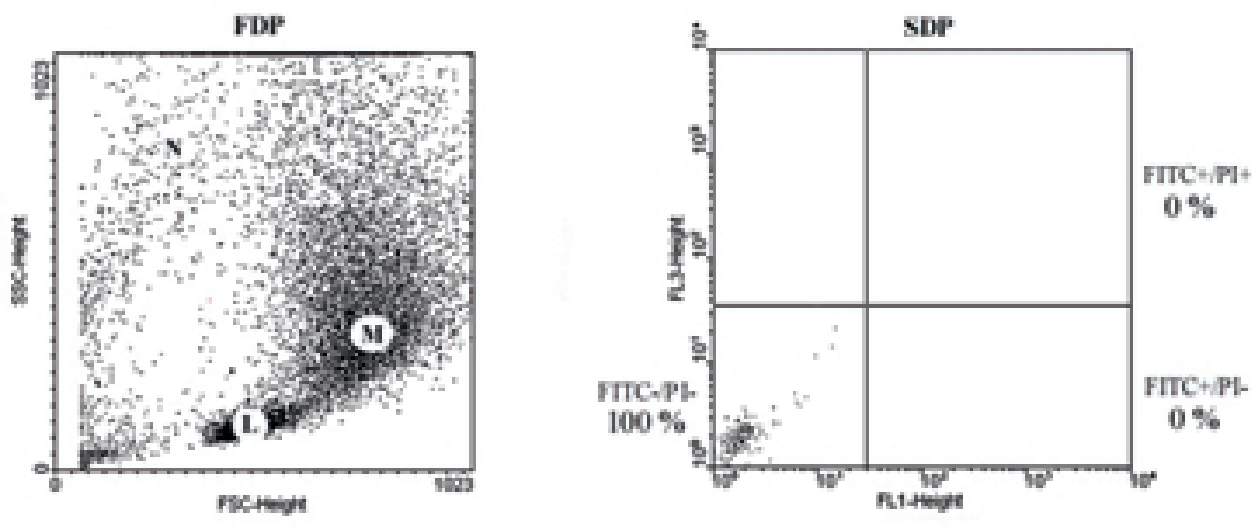

Control
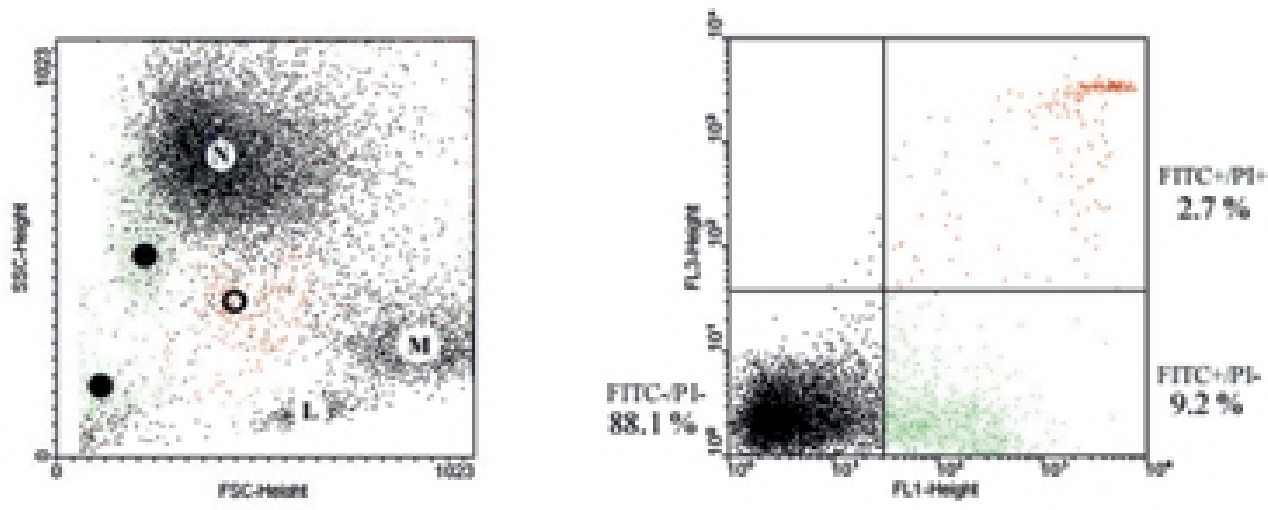

24 hours

Fig. 3-4. Figures in the left column (FDP) represent dot plots of leukocytes gated for scatter parameters during induced influx with PBS. Clusters of neutrophils (N), lymphocytes (L) and macrophages (M) are shown. Subpopulations of neutrophils (green and red) obtained by backgating technique is represented on FDP. Flow cytometry analysis of these ones shows viable (FITC-/PI-, black dots), apoptotic (FITC+/PI,- green dots), and necrotic (FITC+/PI+, red dots) neutrophils gated for Annexin V and propidium iodide during induced influx is represented on SDP. The bit maps (SDP) were set for neutrophils only. One representative out of the five experiments done is shown. 

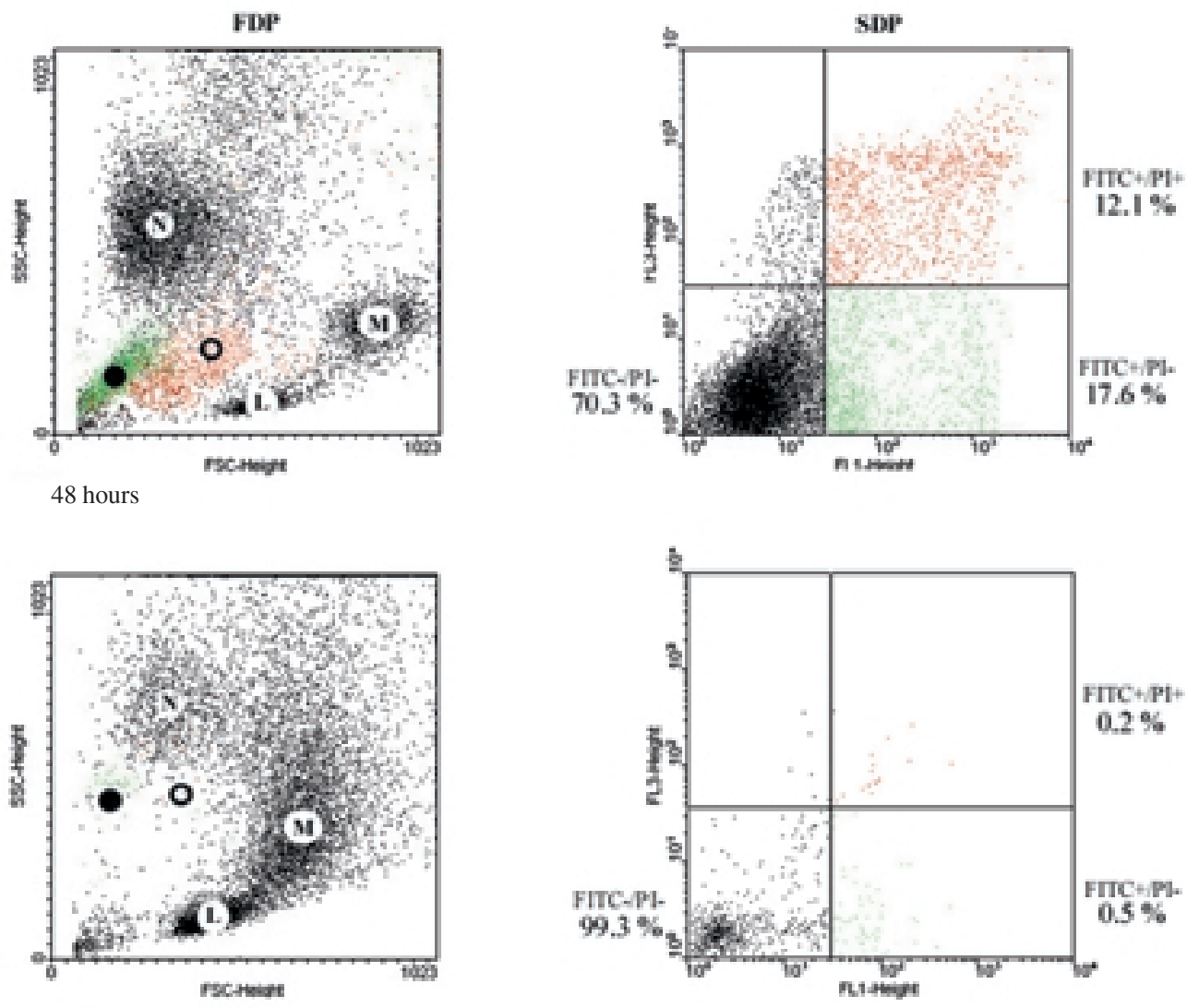

Fig. 4. Text see Plate II. 